\title{
230 \\ VARIA \\ Telewizja interaktywna w Polsce (na przykładzie kanału aMazing Multimedia Polska)
}

\author{
ROBERT KUCIŃSKI \\ Instytut Filmu, Mediów i Sztuk Audiowizualnych \\ Uniwersytet im. Adama Mickiewicza w Poznaniu
}

\begin{abstract}
AвstraCt. Kuciński Robert, Telewizja interaktywna w Polsce (na przykładzie kanału aMazing Multimedia Polska) [Interactive Television in Poland (based on the example of aMazing TV, Multimedia Poland]. „Images” vol. XXVI, no 35. Poznań 2019. Adam Mickiewicz University Press. Pp. 230-238. ISSN 1731-450X. DOI 10.14746/i.2019.35.13.

The article is an attempt to describe the essence of interactive television based on the example of aMazingTV - the first interactive channel in Poland, established by Multimedia Polska in September 2009. The author presents the development of interactivity in life, art and media and reflects on the future of one of the most important features of the so-called new media.
\end{abstract}

KEYWORDS: interactivity, interactive television, aMazingTV

Niemal każdy użytkownik Internetu czy posiadacz smartfonu codziennie staje się uczestnikiem medialnej interakcji. Technologiczne nowinki, które ułatwiają zdobywanie informacji lub ich przekazywanie, na ogół przyjmujemy $\mathrm{z}$ radością, zupełnie naturalnie, a może nawet bezrefleksyjnie. Do walki o uwagę odbiorcy stanęła także telewizja, stwarzając swoim widzom możliwości reagowania na to, co dzieje się na ekranie, i komunikowania się z nadawcą. Mimo że interaktywność - rozmaicie rozumiana - jest jedną z najistotniejszych cech nowoczesnych mediów, to jednak w telewizji przyjęła się w ograniczony sposób.

W licznych definicjach tak zwanych nowych mediów wśród najistotniejszych cech wzbogacających medialny przekaz podaje się nie tylko transmedialność, multimedialność czy zdolność do konwergencji, ale także interaktywność. Technologiczna rewolucja, a właściwie pojawiające się w zawrotnym tempie różnorodne technologiczne innowacje, zdają się w tym obszarze oferować „odbiorcy XXI wieku” nieograniczone możliwości. Każdy człowiek, ży-

[1] M. Składanek, Hipertekst. Pewna historia, „Przegląd Kulturoznawczy” 2014, nr 2 (20), s. 260. jący w cywilizowanym świecie, w środowisku, w którym istnieją media elektroniczne, przynajmniej raz stał się elementem interaktywnego procesu aranżowanego przez medialnego nadawcę. Wielu z nas choćby raz zadzwoniło do radia i usłyszało swój głos na antenie, wysłało sms w telewizyjnym konkursie czy plebiscycie oraz napisało komentarz pod artykułem na stronie internetowej czy „kliknęło” na jedno z wyróżnionych słów hipertekstu, by przenieść się na inną stronę internetową, wyjaśniającą użyte przez autora pojęcie bądź poszerzającą poruszany temat. Internet zdaje się być idealną platformą do uprawiania interaktywności. Wymyślona przez Teda Nelsona już w latach sześćdziesiątych minionego wieku idea hipertekstu znalazła doskonałą (i wciąż udoskonalaną) formę we współczesnych sposobach edytowania tekstów w mediach cyfrowych. „Hipertekst w naturalny sposób stał się punktem wyjścia oraz katalizatorem rozumienia złożonych form komunikacji nowomedialnej, jako że oferował perspektywę najbliższą tradycyjnemu podejściu humanistyki, to znaczy optykę ukierunkowaną na tekst i skomplikowane przejawy tekstualności" [1]. Minęło niewiele czasu, a wszyscy, którzy czytają jakiekolwiek teksty na internetowych 
stronach, chętnie wzbogacają swoją lekturę, korzystając z hiperłaczy wewnątrz tekstu bądź linków umieszczonych pod tekstem. Zupełnie naturalne wydaje się nam „wyposażenie” tekstu głównego (zwłaszcza w przypadku dziennikarskich, promocyjnych i rozrywkowych) w dodatkowe hiperłącza oferujące niezbędne wyjaśnienia, zaproszenia do przeczytania podobnych artykułów, skorzystania $\mathrm{z}$ ofert o zbliżonej tematyce. Coraz bardziej świadomi użytkownicy e-booków oczekują, że tekst, który umieścili w swoim e-czytniku, nie będzie li tylko elektroniczną wersją papierowej książki, lecz raczej hiperksiążką z mnóstwem pożytecznych linków, poszerzających odbiór bądź niebagatelnie wzbogacających jej lekturę. Sporo wielbicieli literatury nadal nie wyobraża sobie „wejścia” w świat wykreowany przez pisarzy bez szelestu i zapachu papieru, ale jednocześnie coraz więcej z nich docenia zalety e-czytników, to znaczy możliwość zabierania ze sobą w podróż sporej liczby książek w jednym małym urządzeniu, powiększania czcionki tekstu czy wreszcie - w wersjach urządzeń połączonych z Internetem - korzystania ze słownika ułatwiającego na przykład poznawanie publikacji w językach obcych. Technologia, owszem, wpływa być może negatywnie na czytanie linearne, ale idea książki jako bazy danych, zbioru cytatów, projektu nigdy-nie-skończonego czy dzieła-zawsze-otwartego już uwiodła zarówno pisarzy młodego pokolenia, jak i czytelników chorujących na lekturowe ADHD. O ile dystrybucja literatury i tekstów naukowych jeszcze przez wiele lat może rozwijać się dwutorowo, to znaczy cyfrowo i analogowo, o tyle świat tekstów dziennikarskich w coraz większej mierze staje się cyfrowy. Każda licząca się gazeta oprócz swej papierowej formy rozwija wersję elektroniczną i internetową. Medioznawcy i wydawcy rozmaicie reagują na hasło głoszące śmierć prasy drukowanej [2], ale czynników wpływających na zmiany w kulturze czytelniczej jest znacznie więcej, więc zwrot odbiorców ku mediom cyfrowym stał się bardzo wyraźny i nieunikniony.

$\mathrm{W}$ wielu domach nie ma już ani stosu gazet, ani nawet radioodbiorników. Najczęściej jest to skutek przemian technologicznych, w efekcie których jedno urządzenie (na przykład telewizor czy komputer) może pełnić kilka funkcji, w tym przekaźnika cyfrowej wersji sygnału radiowego. Nadawcy radiowi także mierzą się z nowymi przyzwyczajeniami słuchaczy, traktujących radio jako medium towarzyszące. Niewielu siada - jak to dawniej bywało - by wysłuchać kolejnego odcinka czytanej powieści czy rozmowy z artystą. Podstawą ekonomiczną działalności radiowej stacji są reklamy, a ich ilość zaczyna odbiorcom przeszkadzać, wszak mają inne źródła, z których mogą czerpać muzyczne nowości, i to takie, które dają się personalizować. Skończyła się era magnetofonowych kaset i chyba kończy się - to bardzo prawdopodobne - czas płyt CD. Aplikacje w telefonie ułatwiają korzystanie z gigantycznych zasobów muzyki i umożliwiają kształtowanie podręcznej biblioteki według własnych upodobań. Muzyczne platformy, dostępne dzięki Internetowi, sięgają ponadto po coraz precyzyjniejsze działania marketingowe zmierzające do customizacji swej oferty. Każdy użytkownik, dokonując estetycznych wyborów, dostarcza właścicielowi czy operatorowi platformy informacje na temat swych preferencji i otrzymuje w zamian propozycje najprawdopodobniej spełniające jego oczekiwania, w postaci na przykład list ulubionych utworów, piosenek najczęściej słuchanych w danym miesiącu, zestawień przebojów utrzymanych w ulubionym gatunku muzycznym itd. $\mathrm{Na}$ przykładzie stacji radiowych najłatwiej można zauważyć efekty konwergencji mediów, polegającej na upodobnieniu form przekazu przez tak zwane media tradycyjne.

Konwergencja mediów musi być również postrzegana jako nadająca sens kulturze medialnej - zaciera granice w przestrzeni medialnej między różnymi kanałami przepływu treści, formami i formatami, segmentami przedsiębiorstw medialnych, czynnościami produkcji i konsumpcji przekazów. Dokonała ponadto jeszcze jednej istotnej zmiany w kulturze medialnej - spowodowała zmiany w sposobie

[2] <https://www.wirtualnemedia.pl/artykul/ prasa-drukowana-przetrwa-ale-jako-towar-ekskluzywny-i-niszowy-opinie> [dostęp: 20.09.1918]. 
korzystania z mediów przez adresatów mediów $z$ biernego na czynny [3].

Stacje radiowe, które do tej pory z upodobaniem celebrowały mit wyjątkowości „spotkania” spikera ze słuchaczem, zmuszone zostały do sięgnięcia nie tylko po formy wypracowane przez telewizję, ale także media internetowe. $\mathrm{W}$ radiowych studiach zamontowano kamery, by słuchacze - poprzez live streaming - mogli obserwować pracę swych idoli, podzielono wywiady na czas ich emisji na antenie i kontynuację w Internecie, przygotowano wielofunkcyjne portale internetowe jako równolegle funkcjonujące platformy informacyjne, a przede wszystkim rozbudowano formy kontaktu ze słuchaczami, by umożliwić im współuczestnictwo $\mathrm{w}$ tworzeniu programu. Prezentacja informacji i muzyki to stanowczo za mało, aby zatrzymać przy sobie dużą grupę odbiorców, stąd lawinowo rosnąca liczba konkursów ( $\mathrm{z}$ coraz atrakcyjniejszymi nagrodami), rozmów ze słuchaczami czy programów uwzględniających ich sugestie muzyczne. Radiowcy już nie tylko czekają na telefony od słuchaczy, ale tworzą również audycje, podczas których dzwonią do nich, by wywołać rozmaite reakcje. Czasami łączą się $z$ dwiema osobami, doprowadzając do konfrontacji. Radiowy prezenter już dawno przestał być „magicznym głosem” bez twarzy, wyposażonym w nietuzinkową wiedzę na temat artystów, a stał się showmanem, którego popularność w dużej mierze zależy od interpersonalnych umiejętności i zgody na multimedialny wizerunek.

Telewizja, z pewnością nie od samego początku swego istnienia, ale mimo wszystko dość szybko, również zaczęła myśleć o możliwości uaktywnienia widzów, o przerwaniu pasywne-

[3] M. Jachimowski, Wpływ konwergencji mediów na ksztattowanie się przestrzeni medialnej, „Rocznik Prasoznawczy" 2012, r. VI, s. 1.

[4] R.W. Kluszczyński, Sztuka interaktywna, Warszawa 2010, s. 3.

[5]J. Janus-Konarska, Nowe media - nowa komunikacja medialna, „Dziennikarstwo i Media 3”

Wrocław 2012, s. 89.

[6] <http://www.kinoautomat.cz/> [dostęp: 16.03.2018]. go odbioru na rzecz nie tylko pełnej koncentracji na atrakcyjności przekazu, ale także - jeśli to było tylko możliwe - współuczestnictwa.

Pierwsze pomysły włączenia odbiorców w akt tworzenia telewizyjnego programu mogły mieć wiele wspólnego $\mathrm{z}$ intermedialną sztuką lat pięćdziesiątych i sześćdziesiątych, której twórcy chętnie dzielili się ze swymi widzami „odpowiedzialnością" za tworzenie dzieła, choć próby włączenia odbiorców w proces tworzenia, trzeba to odnotować, możemy odnaleźć w sztuce znacznie wcześniej, na przykład u Marcela Duchampa. Potwierdzenie tych przypuszczeń odnalazłem u Ryszarda W. Kluszczyńskiego, który zauważa, że

\begin{abstract}
sztuka interaktywnych multimediów posiada swoje uwarunkowania nie tylko w rozwoju technologii informacyjno-komunikacyjnych, lecz posiada również oparcie w tendencjach artystycznych, które rodziły się na przełomie lat pięćdziesiątych i sześćdziesiątych, aby dojrzeć wraz ze sztuką konceptualną; które rozwijały się następnie i przeformułowały w czasie dwóch kolejnych dekad, aby ostatecznie, około połowy lat dziewięćdziesiątych, osiągnąć kształt posiadany współcześnie. Chodzi tu przede wszystkim o konceptualizm, sztuki performatywne, sztukę instalacji. Są one ideowymi poprzednikami intermedialnej sztuki interaktywnej i jej kultury. Sztuka intermedialna i interaktywna powstawała równolegle do ich rozwoju. Sztuka konceptualna i multimedialna często łączyły się ze sobą pokazując, że są dla siebie nieodzowne i tworzyły się dzięki obustronnym oddziaływaniom[4].
\end{abstract}

Niewątpliwie twórcy programów z połowy $\mathrm{XX}$ wieku przenosili na grunt telewizji również doświadczenia teatralne i estradowe - zwłaszcza te, które obliczone były na żywą reakcję obserwatorów. Mimo wszystko we wspomnianych artystycznych wypowiedziach mamy bardziej do czynienia $\mathrm{z}$ interakcją niż z interaktywnością, bardziej z „zaczepianiem” czy pobudzaniem widza do reakcji niż z „dialogiem”, wymianą sygnałów pomiędzy dwoma aktorami komunikacji[5].

O udział widza w twórczym procesie już w roku 1967 pokusili się czescy filmowcy, którzy na potrzeby Expo w Montrealu stworzyli pierwszy interaktywny film zatytułowany $\mathrm{Ki}$ noautomat: człowiek i jego dom[6]. Widzowie 
mogli zadecydować, naciskając jeden $\mathrm{z}$ guzików, jak potoczą się losy bohaterów tej filmowej opowieści, której twórcą był nowofalowy scenarzysta Pavel Juraček. W filmie wyreżyserowanym przez Jána Rohača, Vladimíra Svitačka i Radusza Činčerę główną rolę zagrał Miroslav Horníček, który - pełniąc funkcję moderatora raz po raz przypominał o możliwości głosowania. Zainteresowanie projektem było ogromne, ale po kanadyjskiej premierze i trwającej dość krótko prezentacji tylko w jednym praskim kinie na początku lat siedemdziesiątych władze komunistyczne wstrzymały jego dystrybucję. Do Kinoautomatu powracano jeszcze nie raz w latach dziewięćdziesiątych pokazała go czeska telewizja, a w pierwszych latach XXI wieku jego projekcja stała się niemałym wydarzeniem Letniej Szkoły Filmowej w Uherské Hradiště. Tak naprawdę dopiero standardy zapisu DVD stworzyły szansę na pokazanie wszystkich walorów awangardowego projektu $z$ lat sześćdziesiątych. Z perspektywy dzisiejszych możliwości technologicznych wpisana weń interaktywność była jednak iluzoryczna. Podczas projekcji w Montrealu działały dwa zsynchronizowane projektory, z których jeden był zasłaniany w odpowiednim momencie, a każda $z$ alternatywnych wersji dążyła do tego samego finału.

Pomysł, aby to widz wybrał, jak się ma dana opowieść potoczyć, jak skończyć, wciąż jednak podnieca wyobraźnię nie tylko reżyserów filmowych i telewizyjnych, ale także twórców spektakli teatralnych. Przypomnijmy choćby od lat popularne $\mathrm{w}$ wielu miastach kolejne inscenizacje Szalonych nożyczek - interaktywnej komedii fryzjerskiej Paula Portnera, która zakłada możliwość zadawania pytań widzom i uzależnia rozwiązanie kryminalnej zagadki od ich podpowiedzi.

Do telewizji interaktywność początkowo „wkradała się" poprzez „teleobecność, czyli mniej lub bardziej aktywne uczestnictwo w programie widzów siedzących (i reagujących w rozmaity sposób) w telewizyjnym studiu oraz poprzez wykorzystanie dodatkowych urządzeń, zwłaszcza telefonów. Panie obsługujące telefoniczne linie podczas teleturniejów czy telefo- niczne rozmowy $z$ widzami prowadzone przez gospodarzy programów „na żywo” były stałym elementem wielu rozrywkowych przedsięwzięć. Najpierw głos widza, potem jego twarz (już w dobie Internetu) i wiadomości tekstowe (SMS, czat) powoli rozbudzały apetyt na rozwój komunikacji pomiędzy twórcą/gospodarzem a odbiorcą w obrębie telewizyjnego show.

Kolejne nowinki technologiczne zwiększyły wachlarz możliwości oferowanych telewidzom. Dzięki nagrywarkom PVR mogą obejrzeć dany program później, TimeShift pozwala im na zatrzymanie i opóźnienie prezentacji, a Catch-up na powrót do treści emitowanych przed chwilą. Już od wielu lat abonenci zarówno telewizji kablowych, jak i satelitarnych mają dostęp do biblioteki VoD (wideo na żądanie) i w dowolnej chwili mogą obejrzeć wybrany film czy ulubiony program. Szerokopasmowy Internet połączony z odbiornikiem telewizyjnym zapewnia widzom dodatkowe kanały komunikacyjne i usługi OTT („Over the Top”, czyli usługi poza kontrolą operatora telewizyjnego). Niełatwo rozsądzić, czyje działania - twórców mediów czy widzów - zrodziły nowe przyzwyczajenia odbiorcze oparte na multiscreeningu, to znaczy jednoczesnym korzystaniu z dostarczanych treści prezentowanych w telewizorze, na ekranie komputera, na laptopie i smartfonie. Obserwujemy to, na przykład oglądając talent show „The Voice of Poland" produkowany przez TVP2. Widzowie głosują na uczestników poprzez SMS, "lajkują" ich profile na fanpejdżach, za pomocą telefonicznej aplikacji wcielają się w rolę jurora, czatują z jednym z prowadzących show, a jednocześnie sprawdzają na tablecie czy laptopie, kim jest prywatnie popierany przez nich młody wokalista i jakie ma dotychczasowe osiągnięcia.

Bardzo ciekawym przedsięwzięciem, całkowicie skupionym na idei interaktywności, była powołana do życia w roku 2009 telewizja aMazing. Kanał stworzony przez kablową sieć Multimedia Polska zaproponował szereg programów rozrywkowych, których zadaniem było wyeksponowanie elementu interakcji z widzem, i to interakcji odbywającej się w rzeczywistym czasie przy użyciu pilota do dekodera telewi- 
zji cyfrowej, poprzez naciskanie kolorowych guzików. Czy program powstający w głównej mierze w studiu zlokalizowanym w niewielkim Kaliszu był awangardą telewizji na światową skalę? Otóż nie. Raczej jego inicjatorzy w twórczy sposób podeszli do rozwijanej od kilku lat za granicą telewizji posiadającej interaktywne funkcjonalności pod nazwą red button. Nie tylko w Wielkiej Brytanii, ale także w Australii czy Malezji, widzowie, reagując na podawany przez spikera komunikat 'press the red button', mogli uzyskać dodatkowe informacje o pogodzie lub sportowych wydarzeniach. „Czerwony guzik" podczas piłkarskich Mistrzostw Europy w roku 2004 oraz Mistrzostw Świata w 2006 wykorzystywany był także do nawigacji pomiędzy kanałami, by umożliwić obserwowanie rozgrywek odbywających się w tym samym czasie. Na brytyjskich wyspach już w roku 2003 część głosowania widzów, którzy oglądali popularny talent show pod nazwą „Pop Idol”, odbyła się z wykorzystaniem sygnału zwrotnego wysyłanego przez pilot telewizji cyfrowej.

Pierwszy polski kanał interaktywny wykreowany przez Multimedia Polska był jednak na tle zachodnich „protoplastów” projektem unikalnym. Wszystkie działania podporządkowano w nim rozwojowi komunikacji pomiędzy nadawcą i odbiorcą programu. Bez względu na to, czy to był magazyn filmowy, program kulinarny, poradnik podróżniczy czy motoryzacyjny, w jego przebieg musiała być wpisana interakcja. Program kanału w całości składał się z tak zwanych telewizyjnych formatów interaktywnych, w których swoje siły jednoczyli redaktorzy, scenarzyści i reżyserzy oraz znawcy interaktywnych technologii.

Jednym z popularniejszych punktów w ofercie aMazingTV były programy poświęcone nowościom filmowym, zwłaszcza tym, które tworzyły Domową Wypożyczalnię VoD Multimedia Polska. Powstające po kolei „Gdzie mój pilot?”, „Iluzjon”, „Filmidło” czy „Co w VoDzie piszczy" w zasadzie niewiele różniły się między sobą, bo ich głównym celem było skupienie abonentów na filmowej ofercie przy użyciu siły promocyjnej tkwiącej w procesie interakcji.
Scenariusz programu musiał być tak skonstruowany, by w odpowiednim momencie mogło paść pytanie skierowane do widzów, a widzowie mieli szansę na udzielenie odpowiedzi poprzez naciśnięcie jednego z czterech kolorowych guzików pilota telewizji cyfrowej. Na przykład: prowadzący zadał pytanie, w którym filmie o przygodach Jamesa Bonda zagrała Sophie Marceau. Wyświetlana na ekranie plansza graficzna zawierała oprócz pytania trzy możliwe odpowiedzi: Goldeneye, Jutro nie umiera nigdy, Świat to za mało z przyporządkowanymi kolorowymi punktami - czerwonym, zielonym i żółtym. Guzik niebieski zarezerwowano dla możliwości rezygnacji z zabawy, czyli nieuczestniczenia w interakcji. Po naciśnięciu guzika informacja graficzna znikała, a prowadzący program przechodził do kolejnych filmowych propozycji, informując jednocześnie, że rozwiązanie konkursu nastapi za kilka minut. To niezbędny czas, aby cyfrowe urządzenie zgromadziło i przeanalizowało wysłane dane. W odpowiednim momencie prowadzący powracał do konkursu, podawał prawidłową odpowiedź i uprzedzał, że za chwilę na ekranie pojawi się procentowe podsumowanie głosowania. Kolejna plansza ujawniała, że na przykład 23\% zagłosowało na odpowiedź Goldeneye, $28 \%$ - na Jutro nie umiera nigdy, a $49 \%$ - na Świat to za mało. Najczęściej tylko kilkoro uczestników zabawy mogło otrzymać nagrodę - liczył się zatem czas udzielenia odpowiedzi, jaki upłynął od pojawienia się pytania na ekranie do naciśnięcia guzika na pilocie. Plansze konkursowe z pytaniem, prawidłową odpowiedzią i procentowym podsumowaniem wyświetlały się na ekranie wszystkim widzom, natomiast informację o zdobytej nagrodzie, o treści: „Brawo! Udzieliłeś prawidłowej odpowiedzi w najszybszym czasie. Za chwilę otrzymasz nagrodę", otrzymywali tylko laureaci. Interakcja odbyła się „na żywo”, komunikacja w ostatniej fazie była spersonalizowana, a ponadto uzyskanie nagrody nie wymagało żadnych nakładów finansowych (jak to bywa w konkursach realizowanych za pomocą SMS) czy podawania danych osobowych (bowiem to system identyfikował numer STB abonenta). 
Atrakcyjna była także forma nagrody, bowiem nie trzeba było po nią udać się gdziekolwiek ani czekać na przysłanie pocztą. Już po kilku minutach widz otrzymywał bezpłatny dostęp do filmu z Domowej Wypożyczalni VoD i mógł go oglądać wielokrotnie przez 48 godzin.

Podobną formę konkursowych zabaw oferowały także inne programy telewizji aMazing. Realizowano w niej między innymi „Domowe Kino Tutka” - program filmowy dla dzieci, muzyczne programy „Muzzzik” i „Muzyczne Fanaberie”, „ABS” - dla interesujących się samochodami, programy kulinarne "Gotuj z Multimedia” czy „Gotuj na VoDzie” oraz podróżniczy „Plecak Pełen Wrażeń”. Niektóre z nich wyposażone były w dodatkowe formy interakcji, bowiem w programie muzycznym wola widzów decydowała o kolejnym teledysku emitowanym w ramach programu, a w programie kulinarnym istniała możliwość - za pomocą przycisku na pilocie - bezpłatnego połączenia się z biblioteką VoD, gdzie umieszczono dłuższy film instruktażowy pokazujący, jak przygotować daną potrawę. Ciekawym przypadkiem był wspomniany „Plecak Pełen Wrażeń”, bo w jego interaktywnej części postawiono jedynie na koncentrację widzów i chęć poszerzania wiedzy na temat odwiedzanych przez globtrotera krajów. Pytanie odnosiło się do informacji zawartych w programie, a udzielenie prawidłowej odpowiedzi miało jedynie oglądającym przynieść satysfakcję. Tu także pojawiało się procentowe podsumowanie głosowania, które uzmysławiało, jak wiele osób uważnie ogląda to, co dzieje się na ekranie. Z czasem, gdy twórcy programów aMazing TV - walcząc o liczniejszą oglądalność - zaczęli szukać jeszcze atrakcyjniejszych tak zwanych formatów telewizyjnych, sięgnęli po teleturnieje, w których widzowie mogli nie tylko odpowiadać na pytania wraz z uczestnikami w studiu, ale także decydować o tym, który $\mathrm{z}$ nich powinien opuścić grę albo która $\mathrm{z}$ drużyn powinna otrzymać dodatkowe punkty.

Fiaskiem zakończyły się natomiast próby umieszczenia interakcji w programie informacyjnym, co wydawało się wielce kuszącą możli- wością. Sonda przeprowadzona przez reportera na ulicy nie jest źródłem wiarygodnych informacji, ponieważ ludzie często nie odpowiadają szczerze, a i wybór ich wypowiedzi przez montażystę czy dziennikarza jest dalece subiektywny. Telewizja jednak nie rezygnuje $z$ tej formy gromadzenia informacji, bo $\mathrm{w}$ przybliżony sposób ujawnia ona społeczny nastrój związany z podejmowanym przez reportera tematem. Świadomość, że taka sonda mogłaby się odbywać elektronicznie, anonimowo, podczas emisji wiadomości lokalnych, rozpalał wyobraźnię redaktorów. Na drodze do zawodowej satysfakcji stanęła jednak technologiczna niedoskonałość. Program informacyjny jest na tyle dynamiczną formą dziennikarską, że nie można w nim czekać kilka sekund dłużej na pojawienie się na przykład planszy wieńczącej głosowanie. Zadanie widzom pytania, czy w danej sprawie prezydent miasta wydał ich zdaniem trafną decyzję czy też nie, było bardzo atrakcyjnym punktem programu, ale czekanie na możliwość pokazania procentowego podsumowania głosowania zbyt długo lub wyświetlenie go w momencie omawiania już innego tematu raczej kłóciło się $\mathrm{z}$ ideą sprawnie podawanej informacji. $\mathrm{Z}$ tego względu zrezygnowano $\mathrm{z}$ interakcji w lokalnych wiadomościach, zostawiając tę możliwość jedynie podczas realizacji dłuższych wywiadów z politykami i przedstawicielami władz.

Bardzo obiecująco przedstawiały się również rozwiązania interaktywne w obrębie reklamy. Ciekawą propozycją była możliwość tworzenia krótkiego spotu reklamowego z uwidocznionym w górnym rogu ekranu zielonym punktem i zachęcającym napisem: „Chcesz zobaczyć więcej? Naciśnij!”. Naciskając guzik na pilocie telewizji cyfrowej, widz przenosił się do biblioteki VoD, gdzie czekała na niego pełna informacja o reklamowanym produkcie, na przykład w postaci dłuższego filmu promocyjnego. Ten rodzaj reklamy wzbogacono również o możliwość skontaktowania się z producentem bądź uzyskania jakichś dodatkowych profitów. Dużym zainteresowaniem tę formę reklamowania obdarzyli dilerzy samochodów, ponieważ pozwalała ona pokazać na antenie krótki spot 
236

o samochodzie, dłuższy film na VoD i zaproponować na przykład jazdę próbną wybranym modelem.

Operator MMP mógł (i wciąż może) komunikować się $\mathrm{z}$ widzami za pomocą różnych „wiadomości graficznych" - plansz, interactive messages czy channel banners. Może też umieścić green point, który po naciśnięciu zielonego przycisku na pilocie przeniesie widza nie tylko do konkretnego filmu z Domowej Wypożyczalni VoD, ale także do innego kanału telewizyjnego. Tę ostatnią możliwość skwapliwie wykorzystała grupa HBO i Cinemax, która, dysponując kilkoma kanałami, mogła na jednym z nich zapraszać do oglądania programu lub filmu na innym. Zyskiwała w ten sposób bezpośredni kontakt $\mathrm{z}$ widzami siedzącymi przed telewizorami w najwłaściwszym momencie podejmowania przez nich decyzji, co będą oglądać dzisiejszego wieczoru.

Choć projekt interaktywnej telewizji pod szyldem Multimedia Polska został w roku 2014 w zasadzie zawieszony, to spora część interaktywnych funkcjonalności nadal jest wykorzystywana, jednak już bez wcześniejszego rozmachu, bez ambicji tworzenia telewizyjnego ośrodka interaktywności. Co poszło nie tak? Dlaczego nie udało się odnieść sukcesu za pomocą śmiałego pomysłu i nowatorskiej technologii? Losy aMazingTV niewątpliwie wymagają dokładniejszego opisu i dogłębniejszej analizy, ale domyślać się można, że przyczyn zamknięcia kanału było kilka. Być może należało zainwestować jeszcze więcej pieniędzy, dać programowi większy rozmach i nadać większy rozgłos, być może należało oprzeć show nie na atrakcyjności samej w sobie, ale na gwiazdorskich nazwiskach, być może trzeba było wciąż doskonalić możliwości techniczne, by interaktywny system był zawsze niezawodny i dzięki swojej doskonałości poszerzał grono wiernych odbiorców.

Prawie pięcioletnia działalność aMazingTV uzmysławiała jego twórcom raz po raz, że spora

[7] <https://www.daserste.de/unterhaltung/ film/terror-ihr-urteil/terror-ihr-urteil-goldene-rose10o.html> [dostęp: 20.03.2018]. grupa widzów po prostu boi się używania interaktywnych funkcjonalności, nie wierząc do końca, że decyzje wyrażane za pomocą przycisków na pilocie nie są jednak obciążone konsekwencjami finansowymi, jakąś dodatkową opłatą uwidaczniającą się po czasie w ogólnym rachunku za usługi telekomunikacyjne. Zabrakło zatem edukacji - przemyślanego pakietu informacji i reklam rodzących w abonentach potrzebę uczestniczenia $\mathrm{w}$ interaktywnym procesie.

I jeszcze jedna ważna rzecz. Wszystkie programy pierwszej interaktywnej telewizji polskiej, nawet jeśli zawierały ciekawe pytania z zakresu historii filmu czy geografii, poruszały się w obszarze szeroko rozumianej rozrywki adresowanej do jak najliczniejszego grona odbiorców. Być może zabrakło w ofercie choćby jednej propozycji, która udowadniałaby, że w interaktywności tkwi moc, że jest ona nie tylko ważna, ale także potrzebna.

$\mathrm{Z}$ tej perspektywy bardzo ciekawie wygląda to, co przydarzyło się dramatowi pisarza i prawnika Ferdinanda von Schiracha pt. Terror. W październiku 2016 roku przez niemieckie media przetoczyła się gwałtowna burza zrodzona właśnie przez tę sztukę, którą do swego repertuaru włączyło kilka teatrów, a telewizyjną realizację zaproponowała niemiecka stacja publiczna ARD[7]. Sztuka przyjmuje formę procesu - sądzony jest major Luftwaffe Lars Koch, który samodzielnie podjął decyzję o zestrzeleniu pasażerskiego samolotu porwanego przez terrorystę. Pilot myśliwca miał jedynie obserwować, bo tyle mu wolno. Żołnierz nie może strzelać do cywila, który nie bierze czynnego udziału w walce. W samolocie było 164 pasażerów, ale ten airbus miał uderzyć w stadion wypełniony 70 tysiącami widzów. Sztuka ma dwa zakończenia - winny czy niewinny. Głos ludu wyrażony w teatrach nie odbił się tak szerokim echem, ale podczas spektaklu telewizyjnego zorganizowano głosowanie telefoniczne oraz on-line i prawie $90 \%$ milionowej publiczności orzekło, że Lars Koch jest niewinny. Co to oznacza? To, że głos ludu niemal całkowicie nie pokrył się z literą prawa. I jako ciekawostkę 
podam, że prawo zmieniono. Nie bezpośrednio w wyniku telewizyjnej interakcji, ale... Ten telewizyjny sąd jeszcze dobitniej uzmysławia, że od wieków spora część widowisk sięgała po element interakcji. Przypomnijmy choćby walki gladiatorów i finalny etap, gdy to cezar uwzględniał głos tłumu, podnosząc lub opuszczając kciuk i tym samym decydując o życiu bądź ułaskawieniu jakiegoś pokonanego wojownika. Ale to interakcja prymitywna i niegwarantująca nam rozwoju dialogu, natomiast rozwój technologii pozwala na tworzenie rozbudowanych form interaktywnych. Warto zastanowić się, które z nich mogą liczyć na największą społeczną akceptację, jakie mogą być zyski i straty ich upowszechnienia oraz jaki mógłby być generalny kierunek rozwoju mediów interaktywnych. $Z$ jednej strony dzięki nim niewątpliwie wzrasta komfort widza, który może korzystać z oferty telewizyjnej w indywidualny sposób, $\mathrm{z}$ drugiej jednak - tak to już jest skonstruowane - poszerza się wiedza operatora telewizyjnego na temat upodobań i reakcji odbiorcy, czego efektem jest przygotowanie sprofilowanej oferty. Powstaje zatem uzasadniona obawa, że w krótkim czasie widz, którego „przed chwilą” aktywizowaliśmy za pomocą interaktywności, stanie się widzem biernie akceptującym kolejne propozycje wyświetlane na ekranie. To niewątpliwy zysk dla właścicieli telewizji oraz reklamodawców, ale czy również dla samego widza? Co zrobić, aby interaktywność służyła także widzom, służyła dobrej sprawie, ciekawie rozwijała telewizję, o której coraz więcej ludzi pragnie zapomnieć, traktując ją jako źródło kolorowej i dynamicznej, ale niewyszukanej rozrywki?

Współczesne media cyfrowe, zwłaszcza oparte są na szerokopasmowym Internecie, w zasadzie pełne są interaktywnych elementów. Szukając informacji czy używając aplikacji umieszczonych w smartfonach, tabletach czy laptopach, często już bez zastanowienia stajemy się uczestnikami mniej lub bardziej rozbudowanych akcji interaktywnych. Na razie mniej ufnie spoglądamy na propozycje podobnych działań oferowanych przez telewizyjne kanały. Wszystko jest jednak kwestią czasu. To bardzo prawdopodobne, że młodsze pokolenia nie będą miały zahamowań, które występują jeszcze u ich rodziców i dziadków. Interaktywne teledyski wciąż odczuwane są jako nowość, ale jest ich coraz więcej. Słuchając Black Mirror zespołu Arcade Fire, można włączać lub wyłączać poszczególne instrumenty, a oglądając Just a Reflector tej samej formacji - „zarządzać” oświetleniem. Wraz z premierą słynnego singla Happy Pharrella Williamsa pojawił się pierwszy całodobowy teledysk, będący de facto zapętloną piosenką, w takt której tańczą i którą śpiewają ludzie z całego świata. To od widza zależy, kogo i kiedy ogląda. Zupełnie naturalne będą „interaktywne zachowania" dla dzieci, do których kieruje swą najnowszą ofertę Netflix, emitując interaktywne bajki[8]. Na razie powstały trzy, na razie emitowane są $\mathrm{w}$ Internecie, ale - jak łatwo przewidzieć - tak młoda widownia szybko przyzwyczai się do tego, że może wpływać na losy swych ulubionych bohaterów, takich jak Kot w butach. Przesadą byłoby pisać, że jesteśmy na interaktywność skazani, ale niewątpliwie już za moment stanie się ona bardzo ważnym elementem naszego codziennego obcowania z mediami. Lepiej to sobie uzmysłowić i aktywnie uczestniczyć w interaktywnych procesach niż zostać obiektem medialnej manipulacji - widzem, któremu jedynie wydaje się, że ma na cokolwiek wpływ.

\section{B I B L I O G R A F I A}

Badzińska E., Media interaktywne warunkiem skutecznej komunikacji społecznej, <http://yadda.icm.edu. $\mathrm{pl} /$ yadda/element/bwmeta1.element.ekon-element-000171259733> [dostęp: 17.04.2018]

Castells M., Społeczeństwo sieci, Warszawa 2007

Downes E.J., McMillan S.J., Defining interactivity: A qualitative identification of key dimensions, "New Media and Society" 2000, nr 2

Głowacz F., Dogoń klienta i zarób, „Marketing w Praktyce" 2011, nr 11, s. 24-41

Jenkins H., Kultura konwergencji: zderzenie starych i nowych mediów, Warszawa 2007

[8] <http://wyborcza.pl/7,156282,21995441,netflix-wprowadza-interaktywne-bajki-pomysl-ciekawy-ale-nie.html> [dostęp: 20.03.2018]. 


\section{8}

VARIA

Kluszczyński R.W., Film - wideo - multimedia. Sztuka ruchomego obrazu w erze elektronicznej, Warszawa 1999

Kluszczyński R.W., Sztuka interaktywna, Warszawa 2010

Manovich L., Język nowych mediów, Warszawa 2006

Pisarski M., Xanadu. Hipertekstowe przemiany prozy, Kraków 2013

Projektowanie interakcji, wywiad z I. Knowles, V. Sowerwine i M. Gingoldem przeprowadzony 30 sierpnia 2012 podczas festiwalu Ars Electronica w Linz, w Austrii przez Agnieszkę Słodownik.<http://www. dwutygodnik.com/artykul/3987-projektowanie-interakcji.html> [dostęp: 13.04. 2018]

Raczek M., Interakcja czy sterowanie - polska sztuka przełomu XX i XXI wieku $w$ dyskursie $z$ odbiorca, [w:] Estetyka wirtualności, red. M. Ostrowicki, Kraków 2005, s. 277-293

Składanek M., Hipertekst. Pewna historia, „Przegląd Kulturoznawczy” 2014, nr 2 (20) s. 259-264

Szpunar M., Czym sa nowe media - próba konceptualizacji, „Studia Medioznawcze” 2008, 4 (35), s. $1-40$

Wejman K., Interaktywna sztuka nowych mediów - eksperyment na ciele odbiorcy, „Naukowy Przegląd Dziennikarski” 2013, nr 4, s. 1-17

Zająkała M., Rozwój i standardy telewizji interaktywnej, $<$ https://www.wirtualnemedia.pl/artykul/rozwoj-i-standardy-telewizji-interaktywnej> [dostęp: 3.04.2018] 